\title{
Readiness of UIN Maulana Malik Ibrahim Malang in Implementing Smart Islamic University
}

\author{
Abd. Haris ${ }^{1},{ }^{*}$ Triyo Supriyatno ${ }^{2}$, Samsul Susilawati ${ }^{3}$ \\ 1,2,3 Universitas Islam Negeri Maulana Malik Ibrahim Malang \\ *Corresponding author.Email: triyo@pai.uin-malang.ac.id
}

\begin{abstract}
The success of UIN Maulana Malik Ibrahim Malang in utilizing Information and Communication Technology (ICT) with the term smart Islamic university as a competitive effort and competitiveness in essence lies in a number of indicators such as techno ware, info ware, orgaware and human ware. Efforts to achieve the goals of using a smart campus require a careful planning scheme and thorough need analysis. Many universities fail to implement a smart university due to several things, such as poor planning, unprepared experts, inadequate infrastructure, unavailable initial development costs and inconsistent policies. This study aims to see the readiness of UIN Maulana Malik Ibrahim Malang in implementing a smart campus so that it can be used as a reference in developing the use of ICT on campus. This research uses descriptive quantitative research, namely research that describes an object as it is with the research stages including pre-survey, literature study, questionnaire distribution, data analysis and empirical findings. Data obtained by using a research questionnaire. The results of research conducted at UIN Maulana Malik Ibrahim Malang showed that the development of a cybercampus on the ICT Use component which includes the dimensions of need and harmony as well as the dimensions of process and governance has entered a less prepared stage. The ICT Readiness component which covers the dimensions of technology resources in the category is almost successful. The ICT Capability component which includes the community dimension has not been successful. The ICT impact component has entered the almost successful category. Overall, the cyber campus development component was categorized as nearly successful.
\end{abstract}

Keywords: Smart Islamic University, Cyber University, ICT Implementation, ICT Index, Readiness Index

\section{INTRODUCTION}

Data released by Hotsuite We Are Social on January 2018 showed that the number Indonesian residents who use the internet as many as 132.7 million users or about $51 \%$ of the total population of Indonesia [1]. This data showed accelerated growth in internet users Indonesia which is significant. In 2014 APJII released data on internet users in Indonesia for 107 Million users and predicted growth Indonesian internet users are very significant on the coming years [2].

Observing the number of internet users who have increased significantly, because with the application of the internet which is broadly termed Information and Communication Technology (ICT) one can easily carry out routine activities in real time, without being hindered by place, time and space. This means that geographic boundaries have disappeared because of the existence of the internet [3].

One of the steps to support and improve the quality of service in an institution is the use of ICT. The main objective is for the institution to adapt to existing advances, so that the institution can operate effectively and efficiently[4]. Thus, the use of ICT can have a good influence on the achievement of the vision and mission and objectives of the institution [5].

The development of ICT encourages various educational institutions, especially tertiary institutions, to use the internet in educational management so that using the internet for higher education can improve the quality of graduates who are able to compete both at the national and international levels [6]. Currently, universities can take advantage of ICT as an effort to produce quality 
outcomes. This condition is due to the advantages of the strategic role of ICT, including being able to overcome the problem of gaps in the quality of educational resources and learning models that are starting to become irrelevant [7]

The strategies used to achieve the goal of using ICT are quite difficult. Two important components such as planning and needs analysis must be mature and thorough. Many universities fail to take advantage of ICT. Some of the causes are raw planning, unprepared human resources, inadequate infrastructure suggestions, unavailable costs and inconsistent policies for the use of ICT. Meanwhile, one of the purposes of using ICT in Higher Education is the difference and reduction of higher education operational costs [8].

Higher education can be said to be successful in implementing ICT, seen from a number of indicators, namely tecnoware, infoware, orgaware and human ware [7]. Tecnoware includes the technology that will be used. Infoware includes the information obtained and orgaware covers the management of the application of ICT and humanware, including the management of ICT applications on campus. all of these indicators have an impact on flexibility and quality so that PT can utilize ICT effectively.

The implementation of the use of ICT should be in accordance with scientific studies and in line with technological developments. The implementation of science and technology development must exist a bridge that can connect the two of them so that there is no imbalance that ends in harm and does not reach the final goal. Technology development includes improving quality, increasing the provision of complementary inputs and improving the quality of management. Input and management involve human and material elements. Sometimes the search for input and the implementation of governance does not heed the human side so that the initial principles of technology development are no longer the basis of foundation [9].

The effective and sustainable use of ICT can be realized if ICT has inspired and colored the performance of all university components. ICT can become a strategic issue if ICT can comprehensively affect the attitudes and performance of the components in PT, and no longer achieve false and colossal successes that can be lost for a moment.

This paper aims to identify readiness index UIN Maulana Malik Ibrahim Malang in implementing a smart Islamic university or the use of ICT in university management. So that by knowing the smart Islamic University implementation readiness index, universities can make this information as a barometer in the development of ICT at universities.
A number of universities that have utilized ICT in managing universities use a variety of terms, such as the academic information system campus information system (siakad), e-learning, and some use the term smart university or smart campus. These terms do not yet have an agreed standard or indicator to be used in building an ICT utilization system in the highlands. The lack of standardization is caused by differences in the analysis and needs of each university. Meanwhile, in the united states, a standard has been agreed for the development of network infrastructure called the open science grid (osg). Osg is a scientific standard in building network infrastructure. These standards are used in various fields, one of which is education in higher education [10].

Many universities have developed a variety of information technologies in order to support academic, social and administrative activities [11] This is inseparable from the superiority of this technology which is able to overcome the problems of limited time, space and space. The essence of a cyber campus is a strong collaboration between physical and non-physical systems [12].

The relevant research related to this discussion is the research conducted by Qilbaaini Effendi Muftikhali and Tony Dwi Susanto which discusses the development of e-government. The purpose of this research is to look at the e-government development model and to see its advantages and disadvantages. One of the results of these studies states that in e-government development there are several models and categories in which each category has different measurement objectives, ways and points of view of development [4].

The second relevant research is research conducted by Bertho Molly, Andeka Rocky Tanaamah and Melkior Nikolar Ngalumsine Sitokdana entitled Performance Analysis of Information Systems and Information Technology to Support Employee Performance Using the IT Balanced Scorecard Framework: A Case Study on WiFi Satya Wacana Christian University. This study aims to measure how the level of ICT utilization is based on employee performance. The results showed that there is still a need for additional Human Resources (HR) to help employee performance both in terms of complaint handling and project completion considering that ICT applications are needed and used by all members of the community as well as need to evaluate and upgrade the monitoring application system [5].

Based on the two studies above, it is concluded that to develop ICT in an institution, in this case a university requires a development model and different categories considering that each category has different characteristics and measurement methods. Human resources are very much needed in the development of 
ICT in an institution. Mainly used for monitoring ICT implementation applications in universities.

\section{METHOD}

The type of research used descriptive quantitative or it was also mentioned as a survey approach [13] where the researcher asks several respondents (samples) about beliefs, opinions, characteristics of an object and past or current events. This research was conducted to take a generalization from a study. Quantitative descriptive research collects data by using a research instrument in the form of a questionnaire and data analysis is descriptive quantitative.

The stages of research activities are as follows: (1) Pre-survey. The pre-survey was carried out in order to see current conditions (cuurent system) and problems associated with development of a cyber campus. (2) Literature Study. Conducted to find theories and concepts related to research in a way studying journals or books relate to objects and problems research. (3) Spread of
Questionnaires. The questionnaire used is a questionnaire model in the ICT Pura program. Questionnaire compiled based on 4 (four) components, namely ICT Use, ICT Readiness, ICT Capability, and ICT Impact. After the questionnaire is compiled, it is distributed to the sample who have been selected as many as 155 samples. (4) Data Analysis. Questionnaires that have been filled in and returned by samples, analyzed using a formula index measurement with 3 (three) dominance, namely entity mapping, index calculation as well rating. Ranking meant giving a position or on a category where is the readiness of a college deep implementation of ICT. (5) Empirical Findings. Based on data analysis, the results of data processing can be interpreted. In this stage the readiness position will be obtained college on ICT implementation or a cyber campus.

Population and Sample this research was conducted at UIN Maulana Malik Ibrahim Malang with the population is the entire academic community consisting of Leaders, Lecturers, Students and Employees. The population number can be seen in table 1. the following:

Table 1. Research Population

\begin{tabular}{|c|l|c|}
\hline No & \multicolumn{1}{|c|}{ Type Population } & Amount \\
\hline 1. & Leaders (Rector/Vice Rector/Directur) & 28 \\
\hline 2. & Lecturers & 726 \\
\hline 3. & Students & 4118 \\
\hline
\end{tabular}

\section{Sources: EMIS UIN Maulana Malik Ibrahim Malang 2019}

The number of sample members is based on technique sampling used. Several sampling techniques and the number of samples in this study is seen in table.

Table 2. Research Sample Table
The following 2. The number of sample members is based on technique sampling used. Several sampling techniques and the number of samples in this study is seen in table. 2 the following.

\begin{tabular}{|c|l|l|c|}
\hline No & \multicolumn{1}{|c|}{ Population Type } & \multicolumn{1}{c|}{ Sampling Technique } & Amount \\
\hline 1 & Leaders & Purposive random sampling & 28 \\
\hline 2 & Lecturers & Simple random sampling & 27 \\
\hline 3 & Students & & 100 \\
\hline \multicolumn{2}{|c|}{ Total } & 155 \\
\hline
\end{tabular}

Purposive random sampling was used with considerations that will be sampled are all existing populations, namely the leadership of university. Simple random sampling is used because of population assumed to have no levels or strata, while the use of stratified random techniques sampling because active students consist of levels, namely semesters $1,3,5$ and 7. Each level is taken randomly as many as 25 samples.

The instrument used for this research refers to the instrument model used in the ICT Pura program. Compiled instrument based on 4 (four) components, namely ICT Use, ICT Readiness, ICT Capability, and
ICT Impact and 5 (five) dimensions, namely; dimensions of needs and alignment, process and governance dimensions, dimensions technological resources, the community dimension and the output and benefit dimensions [7]. To accommodate all the components and dimensions above, 150 items were arranged instrument.

The instrument used is an instrument non-test is a questionnaire. The questionnaire was prepared using Likert model scale uses 6 (six) options the answer weighs 0 - 5. The research instrument is not use positive and negative measurements but using the concept of proportional measurement means the weight given based on the size the insignificance of the measured aspect value in field [14]. 
The instrument is valid and reliable the main indicator in producing that research valid and reliable. A valid instrument must be having internal validity and external validity. Instruments that have internal validity are instruments that have the same criteria theoretical has reflected what was about be measured. While the instruments that have external validity is a structured instrument refer to the facts found [13]. The validity of the research instrument is the extent to which the research instrument is able to capture the actual meaning of what it wants to measure [15].

Research instrument to be measured is Internal validity and external validity instrument. The internal validity of the instrument is construct validity (construct validity) which is arranged based on empirical facts with indicators that measuring instruments can be used to measure predefined variables. As for how to measure the validity of the internal instrument in the form of construct validity, namely with consult an expert. Validity testing external by doing comparisons among the indicators contained in instrument with facts in the field. If there aren't differences between criteria and facts in the field, it can be stated that the instrument has external validity.

The ICT Pura paradigm is used as a reference for analysis of the use of ICT in university. There are 3 (three) domains or domains of measurement, namely: the domain of entity mapping, the domain of calculation index and ranking domain. Three realms the use of ICT is shown in Figure 1 below.

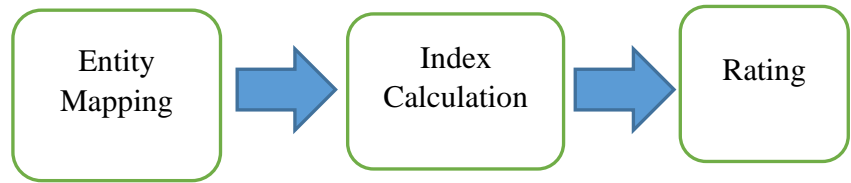

Figure 1. Domain of ICT Implementation

The main focus of the entity mapping domain is the situation and condition of the ecosystem that includes 5 (five) dimensions, namely: First; needs dimension and the alignment associated with needs and expectations of all components or stake holders at College. Second; process and order dimensions manage the implementation and consists of 4 (four) activities, namely: planning and organizing, development and procurement, implementation and management and controlling. Third; dimensions infrastructure consisting of network, hardware, software, database and information as well as human resources. Fourth; The community dimension, namely Head of university; Lecturer; College student; PTIPD unit staff (Information Technology Center and Database). Fifth; output and outcome dimensions which are results system that will be felt by all components at PT. The five dimensions are shown in the figure. 2 .

The index calculation involves 4 (four) components to be measured are components use (ICT Use), a readiness component (ICT Readiness), a component of the ability (ICT Capability) as well as the impact component (ICT Impact) from implementation of ICT. As for the weighting in this index calculates $40 \%$ for ICT Use, this remember all activities based on policies, regulations, and decisions of the leadership of university. The ICT Readiness component is assigned a weight of $20 \%$. The consideration is the availability of infrastructure is the basic foundation for the implementation of ICT in PT. The ICT Capability component is given a weight of $25 \%$. The consideration is that PT will develop if it has the resources and capabilities enough. The ICT Impact component is given a weight of $10 \%$ with the consideration that the academic community will benefit directly from the presence of ICT.

Based on predetermined weight values, an ICT or smart campus implementation index can be obtained using the following formula:

Indeks $=\mathrm{NR}_{\mathrm{IU}} * 40 \%+\mathrm{NRIR} * 20 \%+\mathrm{NR}_{\mathrm{IC}} * 25 \%+$ $\mathrm{NR}_{\mathrm{II}} * 15 \%$

$$
\begin{aligned}
& \mathrm{NR}_{\mathrm{IU}}=\text { Average for ICT Use } \\
& \mathrm{NR}_{\mathrm{IR}}=\text { Average for ICT Readiness } \\
& \mathrm{NR}_{\mathrm{IC}}=\text { Average for ICT Capability } \\
& \mathrm{NR}_{\mathrm{II}}=\text { Average for ICT Impact }
\end{aligned}
$$

The ranking is based on the amount value A smart campus implementation index is obtained based on the formua above. Use of scale models Likert is used in the scoring system that is between 0 up to 5 with the following meanings:

$0=$ Smart Islamic University implementation failed / not Ready

1 = Implementation of Smart Islamic University is not ready

$2=$ Smart Islamic University implementation is almost ready

3 = Smart Islamic University implementation is ready /was successful

4 = Smart Islamic University implementation is ready and able to compete

$5=$ The implementation of Smart Islamic University is very good was successful

With this ranking, UIN Maulana Malik Ibrahim Malang height will be able to see the implementation position of Smart Islamic University.

\section{RESULT AND DISSCUSION}

The research data is presented based on structure or research variables under study, namely dimensions and components. 


\subsection{Dimensions of Smart Islamic University development}

Based on the data collected, it was found that the score for the compliance and alignment dimensions was 3,967, the process and management dimension dimensions were 2,675, the technology resource availability dimension was 3,907, the community dimension was 2,915 and the score for the output and benefit dimensions was 3,800. The distribution of scores from the sample answers can be seen in table 3 and figure 3 .

Table 3. The value of the dimensions of the smart Islamic University Implementation

\begin{tabular}{|l|c|}
\hline \multicolumn{1}{|c|}{ Dimension } & Value \\
\hline Meeting Needs and Harmony & 3.967 \\
\hline Implementation Process and Governance & 2.675 \\
\hline Availability of Resources & 3.907 \\
\hline Stakeholder Support & 2.915 \\
\hline Outputs and Benefits & 3.800 \\
\hline
\end{tabular}

\subsubsection{Dimensional data of requirements and alignment}

There are 8 (eight) instruments related to the dimensions of necessity and harmony. The research data that has been presented above can be interpreted as a score of 2,875, which means that in the development of a smart Islamic university this dimension is almost ready and ready because the scores obtained are in the range 23 like the predetermined range. From these data, it can be concluded that the dimensions of need and harmony have met the readiness requirements in order to develop a smart Islamic university at UIN Maulana Malik Ibrahim Malang.

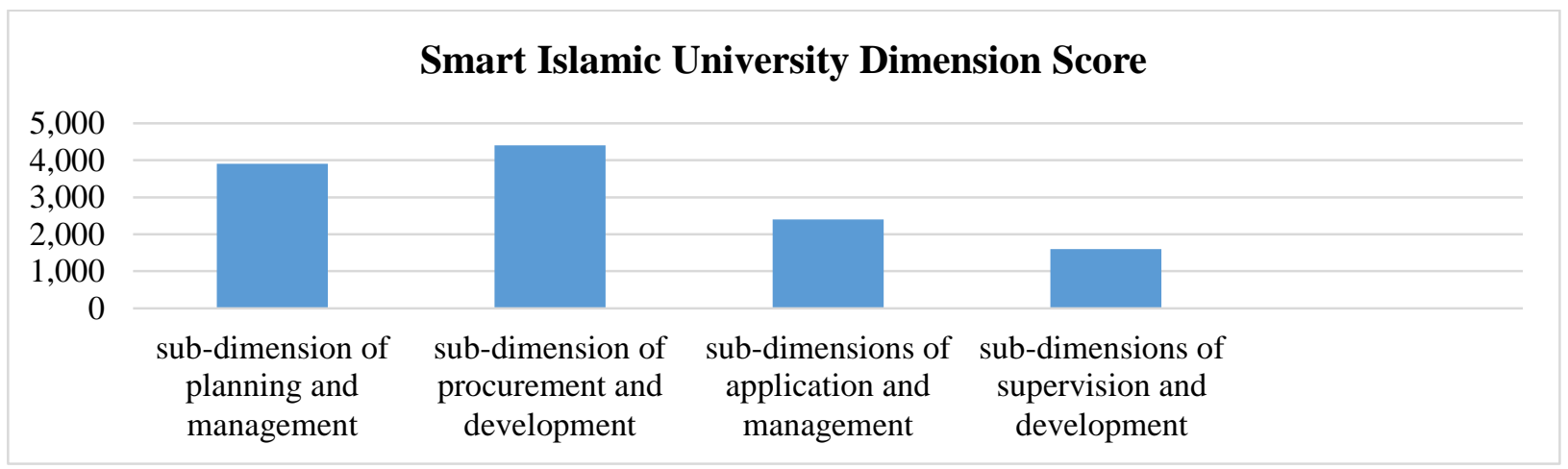

Figure 2. The distribution of the Smart Islamic University Implementation Dimensions Score

\subsubsection{Process and governance dimension data}

This dimension has 4 (four) sub dimensions, namely planning and management obtained a score of 3,900, subdimension of procurement and development amounting to 4,400, the sub-dimensions of application and management obtained a score of 2,400 and sub the dimensions of supervision and development of 1,600. The distribution of scores for this sub dimension can be seen in figure 3 below.

\section{The sub-dimensional score on the process dimension and management governance}

sub-dimensions of supervision and development sub-dimensions of application and management sub-dimension of procurement and development sub-dimension of planning and management

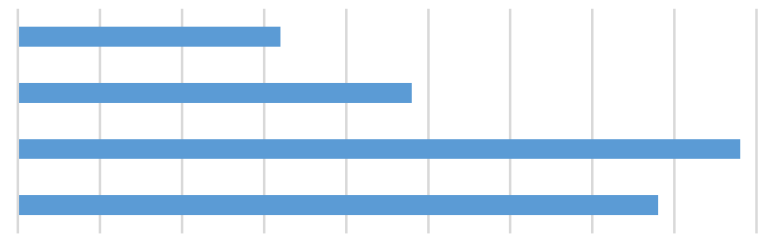

$05001,0001,5002,0002,5003,0003,5004,0004,5005,000$

Figure 3. Distribution of sub-dimensional scores on the process and governance dimensions 
In the sub-dimension of planning and organizing the score obtained is 3,900, meaning that this sub-dimension is still not ready to welcome a smart Islamic University, but is ready. Meanwhile in the sub-dimension of procurement and development, the score obtained is 4,400 , meaning that this sub-dimension is ready to develop a smart Islamic university. In the implementation and management sub-dimensions, a score of 2,400 was obtained, the sub-dimensions were categorized as ready for smart Islamic University development. While the subdimension of supervision and development has a score of 1,600 , this dimension is classified as a very prepared subdimension. Based on the four sub-dimensions in this dimension, a score of 2,575 is obtained, with this score indicating that the process and governance dimensions are categorized as ready.

\subsubsection{Technological resource dimension data}

This dimension has 4 (four) sub dimensions, namely sub the network infrastructure dimension that obtained the score 4.738, hardware sub-dimension and access with score of 4,667, sub-dimensions of data, information and knowledge with a score of 3,533 and competence individuals with a score of 3,624 . As for the distribution of scores in this dimension can be seen in figure 4 at below.

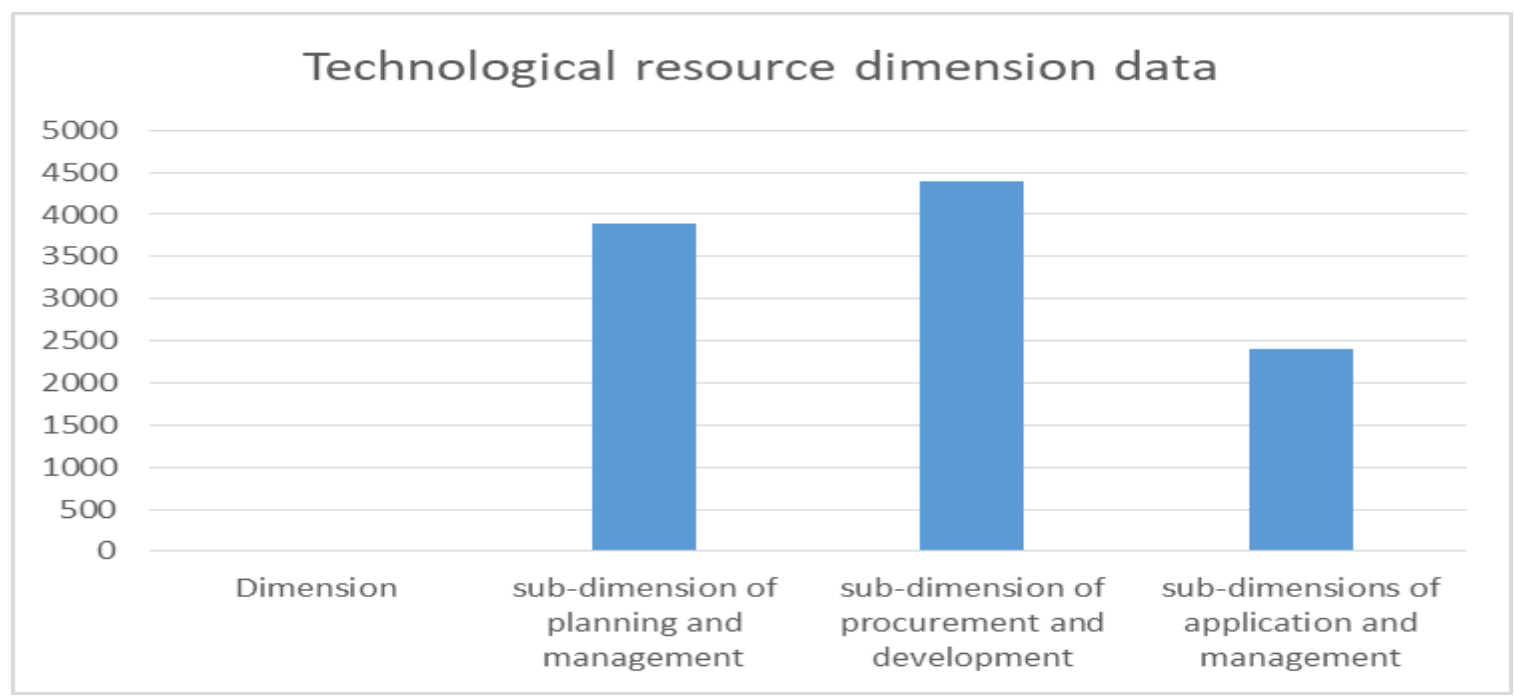

Figure 4. Distribution of sub-dimensional scores on the resource dimension technology

Sub dimensions of a network infrastructure obtained a score of 4,738 , which means that this sub-dimension is ready for the development of a smart Islamic University. While the hardware and access channel sub-dimensions get a score of 4,667, with this score, this sub-dimension is categorized as ready and able to compete. The subdimension of data, information and knowledge with a score of 3,533 is categorized as ready. And the individual competency sub-dimension with a score of 3,624 means that this sub-dimension is categorized as ready for a Smart Islamic University.

\subsubsection{Community dimension data}

In this dimension there are 4 (four) subdimensions, namely the leadership sub-dimension with a score of 3.430, the lecturer sub-dimension with a score of 4.145 , the student sub-dimension with a score of 4,134 and the manager sub-dimension with a score of 4,000. The distribution of scores for the community dimension can be seen in Figure 5. Below:

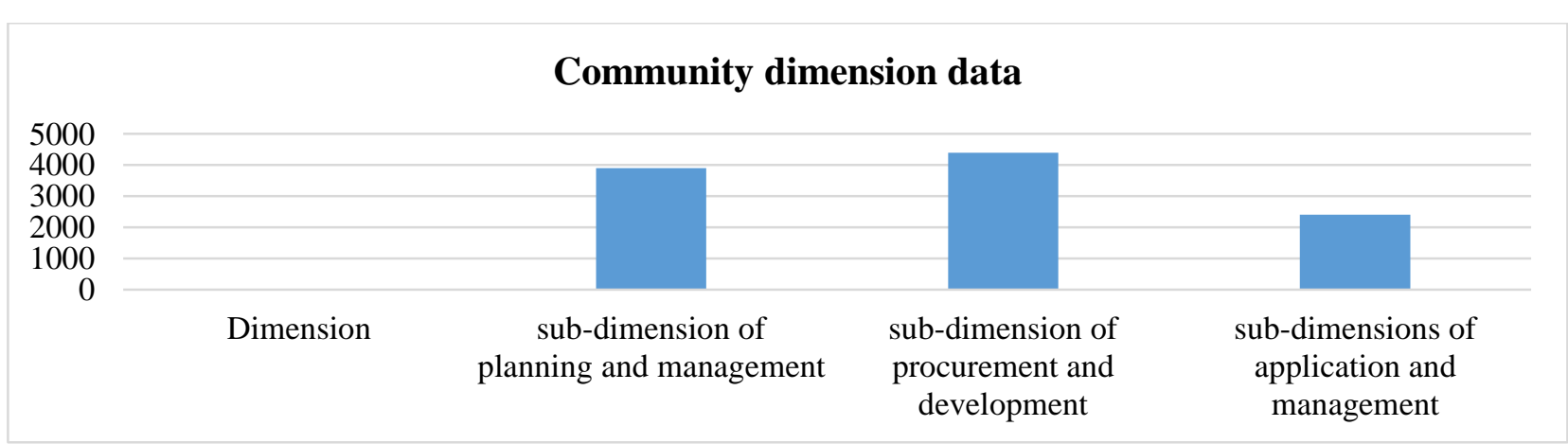

Figure 5. Distribution of sub-dimensional scores on the community dimension 
Sub-dimension leadership with a score of 3,430, meaning that the leadership has made a significant contribution in the form of policies to support development smart islamic university, this can be seen from the score obtained categorized on the ready or adequate scale Ready. Subdimensions of lecturers with the scores obtained 4,145 very ready to face the development of smart islamic university is proven by the score scale obtained is on the scale very ready. Meanwhile, the student sub-dimension with a score obtained of 4.134 too indicates that this sub dimension is ready in developing a smart Islamic university. Sub dimensions last in this dimension is the maintainer obtained a score of 4,000 , this data shows that the manager has entered the ready for phase development of smart Islamic university.

\subsubsection{Output and benefit dimension data}

The data obtained for the output dimensions and the benefit is about 3,900. This data shows that this dimension has entered the almost ready phase in developing a smart Islamic University.

\subsection{Smart Islamic university development components}

The five dimensions above are sub components of the 4 (four) development components smart Islamic university models, namely ICT Use, ICT Readiness, ICT Capability and ICT Impact. Score obtained for the ICT Use component of 2,446, component ICT Readiness obtained 2,739, the ICT component Capability with a score of 1,852 and the ICT component Impact with a score of 2.9.00. Score distribution for the four components can be seen in table 4 and figure 6 .

Table 4. Values of smart Islamic University development components

\begin{tabular}{|l|c|}
\hline \multicolumn{1}{|c|}{ Components } & Value \\
\hline ICT Use & 2.446 \\
\hline ICT Readiness & 2,739 \\
\hline ICT Capability & 1,852 \\
\hline ICT Impact & 2.900 \\
\hline
\end{tabular}

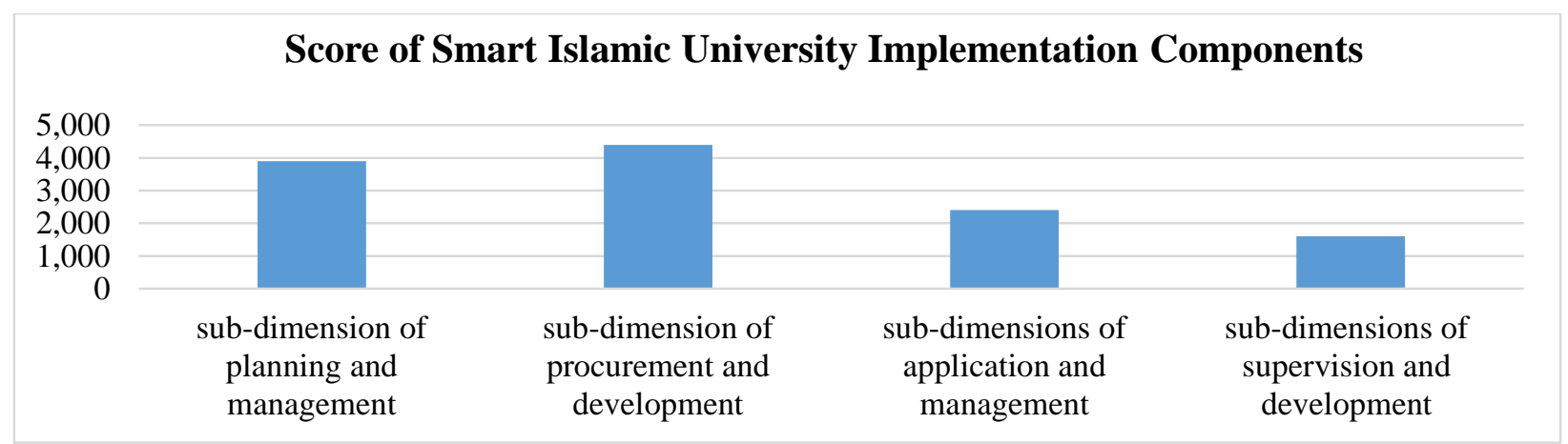

Figure 6. Distribution of scores for Smart Islamic University implementation components

\subsubsection{ICT Use Components}

This component consists of the dimensions of needs and the alignment and dimensions of processes and governance. This component includes matters related with needs analysis and identification the need for development aspects smart campus and matters related to needs and wants of various components in university to the existence of ICT in various contexts activities at the university. This component is very closely related to the policy to be taken by stakeholders one of them is the leader of the university. Some including how the policy planning and organizing a smart Islamic university, procurement of infrastructure and development and development and supervision of development activities that have been and will done. Based on data obtained from the results of research for this component amounted to 2.446, this score indicates that the ICT Use component categorized as ready for development smart Islamic university at UIN Maulana Malik Ibrahim.

\subsubsection{ICT Readiness Components}

The ICT readiness component consists of dimensions technology resources that include infrastructure network, hardware and access channels, data information and knowledge and competency of resources human. Based on the results of this component research obtained a score of 2,807 . this figure indicates that this component is on position almost ready and approaching was ready for development of smart Islamic university.

\subsubsection{ICT Capability Components}

The ICT capability component includes dimensions community who will become users of smart Islamic university consisting of leaders, lecturers, managers and 
students. Based on research data this component obtained a score of 1,914. Numbers This shows that the assumptions of the top users the importance of smart campus is still very low bias is caused that the potential users haven't or don't know or haven't felt the impact from using the smart campus. This component is in a position that is not ready and almost ready for the development of a smart Islamic university.

\subsubsection{ICT Impact Components}

This component is related to "outcome" or the "value" felt by the components in campus with the implementation of various applications ICT in smart Islamic universities. This component will be the final indicator of implementing a smart campus because of the success or failure of smart development campus will be felt on this component. Based on data obtained from research, this component obtaining a score of 2,900 , this figure shows that the development of a smart Islamic university at UIN Maulana Malik Ibrahim Malang is almost successful and is close to being successful.

\section{CONCLUSION}

The development of a smart Islamic University at UIN Maulana Malik Ibrahim has tried to use a system development model. Cyber campus development in components ICT Use which includes the dimensions of needs and alignment and dimensions of processes and governance in UIN Maulana Malik Ibrahim has just entered the stage Ready. While the ICT Readiness component is including the dimensions of technological resources already on successful category and entered the category has succeeded. ICT Capability component which includes the community dimension is approaching the category was successful. Meanwhile, the ICT impact component already entered the category approaching has been successful. Overall a development component the smart Islamic University at UIN Maulana Malik Ibrahim Malang is categorized was successful.

Based on the results of this study, it can be recommended to UIN Maulana Malik Ibrahim Malang to make information related to the readiness index implementation of ICT on campus as a reference and considerations in the context of developing ICT in the future towards a more perfect smart Islamic university.

\section{REFERENCES}

[1] H. we are social, "Indonesia Digital Landscape," Special reports digital in 2018: world's internet users pass the 4 billion mark, 2018.

[2] APJII, "Internet User Profil Pengguna in Indonesia 2014," 2014.

[3] K. K. R. Choo, "The cyber threat landscape: Challenges and future research directions," Comput. Secur., 2011, doi:

\subsection{6/j.cose.2011.08.004}

[4] Q. E. Muftikhali and T. D. Susanto, "Kumpulan Model Maturity E-Government: Sebuah Ulasan Sistematis," Kumpul. Model Matur. EGovernment Sebuah Ulas. Sist., 2017, doi: 10.25126/jtiik.201744367.

[5] B. Molly, A. R. Tanaamah, and M. N. N. Sitokdana, "Analisis Kinerja Sistem Informasi dan Teknologi Informasi untuk Menunjang Kinerja Karyawan Menggunakan Framework IT Balanced Scorecard (Studi Kasus pada Wi-Fi Universitas Kristen Satya Wacana)," J. Teknol. Inf. dan Ilmu Komput., 2017, doi: 10.25126/jtiik.201744499.

[6] A. Kumar Bairagi, S. A. A. Rajon, and T. Roy, "Status and Role of Ict in Educational Institution To Build Digital Society in Bangladesh: Perspective of a Divisional City, Khulna," Int. J. Adv. Eng. Technol., 2011.

[7] R. E. Indrajit, "Profil dan Panduan Pelaksanaan Program ICT Pura.” pp. 1-107, 2011, Accessed: Nov. 11, 2020. [Online]. Available: mozextension://ff730480-d4ef-42a8-bbf46d89a572a043/enhancedreader.html?openApp\&pdf=https $\% 3 \mathrm{~A} \% 2 \mathrm{~F} \% 2 \mathrm{~F}$ web.kominfo.go.id\%2Fsites $\% 2$ Fdefault $\% 2$ Ffile s\%2FBuku_Profil_dan_Panduan\%2520_Pelaksa naan_Program_ICT_Pura_1.60.pdf.

[8] I. Jung and I. Rha, "A Virtual University Trial Project: Its impact on higher education in South Korea," Innov. Educ. Teach. Int., 2001, doi: 10.1080/147032901300002837.

[9] A. Saefuddin, No Title. Jakarta: PPA Consultants, 2010.

[10] D. Weitzel, B. Bockelman, D. Fraser, R. Pordes, and D. Swanson, "Enabling Campus Grids with Open Science Grid Technology," 2011, doi: 10.1088/1742-6596/331/6/062025.

[11] I. Han and S. Han, "Adoption of the mobile campus in a cyber university," Int. Rev. Res. Open Distance Learn., 2014, doi: 10.19173/irrodl.v15i6.1950.

[12] E. A. Lee, "The past, present and future of cyberphysical systems: A focus on models," Sensors (Switzerland). 2015, doi: 10.3390/s150304837.

[13] Sugiyono, Metode Penelitian Kombinasi (mixed Methods). 2018.

[14] S. Zakir, "Islamic Cyber Campus (ICYCA) dan Pengukurannya Menggunakan Paradigma ICT Pura (Sebuah Model Pengembangan ICT di Pengajian Tinggi)," J. Chem. Inf. Model., 2014.

[15] M. Lee Abbott and J. McKinney, Understanding and Applying Research Design. 2013. 